\title{
The Phenomenon of Financial Integration and the Probable Issues in Financial Alterations Related to EU
}

\author{
Ahmet Niyazi Özker \\ Department of Public Finance, Faculty of Economic and Business Administration, Bandirma Onyedi Eylul University, Turkey
}

Copyright $@ 2019$ by authors, all rights reserved. Authors agree that this article remains permanently open access under the terms of the Creative Commons Attribution License 4.0 International License

\begin{abstract}
The financial integration concept is a very important main key, as an integration phenomenon, that haven taken place in EU, and effect on the member countries' financial reform process for a long time. In this study, we aim to put forth the financial relations between financial alterations and recent developments, which include along the capital movements especially together with the last full member countries. Therefore, we have interrogated two cross-examine related to financial integration fact. That is first of their financial market standards affecting financial harmonization adjustment process. Secondly, the financial risk-sharing and prudential policies' effect that take place in applications related to integration process. In addition to, the price-based policies have been emphasized along the occurred global risks which make sense cross-country dispersion of bond yields among banks in the EU. However, since the process of financial integration represents a process that aims to harmonize national debt limits between member states, it also presents a process where the money market transactions are also questioned among banks on a global level. In this respect, the global alignment of financial markets emerges as the objectives of joint financial change as well as the alignment of macro financial indicators for EU countries, and it appears that this fact makes corporate integrations inevitable among member countries.
\end{abstract}

Keywords European Unity (EU), Financial Integration, Financial Markets, National Debts, Price-based Policies

\section{Introduction}

The phenomenon of financial integration has constituted an important intensive framework for structural debates among the member states of the European Union. These structural debates attempt to express the financial common values of the member states of the European Union, but also cover some studies aimed at their institutional integration. Financial risk sharing in the European Union is created through the provision of monetary union and every financial institution that constitutes a financial risk contributes to financial integration at its own level. The financial integration requires capital markets to be supported by financial institutions, and all structural changes in the real development levels, including technological developments, have also aimed at integrating capital. In the context, it appears that the occurred main problems are due to composite bank lending alteration rates for non-financial corporations that include all the member countries, and their cross-country dispersions. In this respect, the primary objective of the study is to overcome the structural integration problems and emphasize more clearly the dynamics of integration in the process for EU.

The first of their is the recent financial turbulences in EU that couldn't been ensure the process of financial re-integration due to the circulated financial stock values from the capital markets of emerging stock market economies or from economic-political uncertainties of the member countries. The study conducted by Masoud (2013) [21] emphasize in terms of the quantitative deviations of the effects of deviations caused by the economic and political uncertainties experienced among the member states of the European Union. Especially, these deviations in this study have been considered on the based stock-capital markets and market failures related financial integrations in EU. Second, a common consensus of market dynamics scholars from financial markets differentiates the benefit scales that countries expect. It is possible to express this phenomenon as an asymmetric information phenomenon, which has a negative impact on the differentiation of financial markets and financial integration [16]. This phenomenon is a structural divergence process in which negative financial information standards are differentiated and it is seen that it pushes the perception of institutional market to a different process against integration. This process, based on the standard deviation of knowledge in the European Union, also provides a structure in which financial integration must be addressed through different policies. Another study that 
draws attention with the approaches in the establishment of protective financial policies is the study by Pierdzioch (2002) [24]. In this study, it is emphasized that the monetary conservative policies of the European Union should be overcome and it is argued that the effect of possible financial shocks can be reduced in this way. This study can be accepted significant in terms of putting current emphasis on the contradictions of the monetary policy in the European Union in recent years [29]. The third, turbulences based on financial integrations is observed to emerge from non-conformities with monetary policies, and the contradictions created by price-based integration policies among different monetary values are frequently on the agenda by Niemann and Ioannou (2015) [23] have confirmed this approach in their study of the European Union. In the study, the emphasis is placed on the management dynamics of the economic and monetary union within the scope of the European Union and the negative effects of the possible financial crises on financial integration including different financial policies [11].

\section{The Structural Alteration Dynamics of the Financial Integration Process Aimed at the Desired Goals in EU}

The financial integration process in the EU should be considered as a communication process with the own internal dynamics as well as an intensive working platform for the member countries. In this respect, it appears that the financial integration includes the expression of a structural analytical process as well as the different national dynamics of countries as a sectoral institutionalization process. Since a long time EU countries concentrate on a clearer and integrated integration of regional financial capacities as well as a common financial capacity work [1]. At this point, the understanding and analysis of the asymmetric structure of the financial dynamics of the EU reveals clear structural dynamics in both the joint financial decisions and the framing of possible financial reforms. Therefore, the understanding of the financial integration dynamics reveals the different contribution levels of the member countries at different levels of development, and this fact means the redefinition of new-current functional integration dynamics including also politic contradictions [4].

\subsection{The Politic Dilemmas Related to EU Countries in the Financial Integration Process}

It is obviously clearly that the financial integration process should ensure more institutional knowledge directed to the cross border countries should provide information to put forth capacity building. In the EU integration process, the negative effects of political contradictions and dilemmas on the integration process are the result of the fact that the search for common ground especially on financial platforms - cannot be achieved with sufficient clarity. These contradictions in the search for common financial ground reveal the search for a common analytical work program. This process, in which information sharing also becomes an asymmetric information sharing among the member countries, constitutes a justification for shifting the borders of neighboring countries to different institutional grounds for financial integrations [22]. On the other hand, the political basis of these infrastructure dynamics put forth a macro position of the integration process. In particular, the contradictions created by monetary policy implementations reveal a negative impact on financial integration as a result of the negative movement of free capital on the basis of EU members. These internal dynamic relations can be put forth as seen on figure 1 , below:

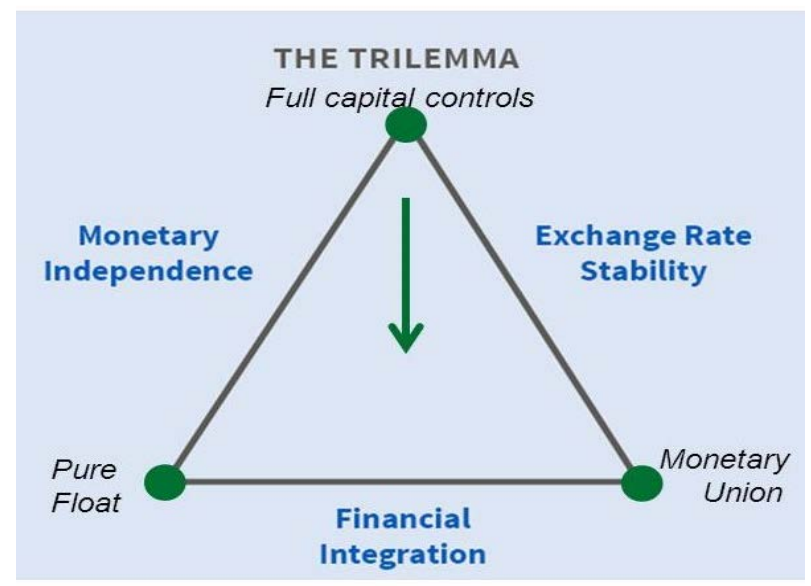

Source: Macro Ops,

https://macro-ops.com/chinas-mundell-fleming-trilemma/

Figure 1. The Conflict Dilemma Dynamics aimed at The Integration Process in EU Countries

In the frame of figure 1 , we need to emphasize undoubtedly that these financial dilemmas and structural contradictions that are related to internal dynamics are the conflicts arising from the different exchange rate conflicts as well as the conflicts on the using sharing of monetary authority aimed at the free capital circulation. In fact, this process, in which the targeted monetary union is directly adversely affected by the contradictions between the national monetary union and exchange rate changes, is another expression of a contradictory structure in which financial integrations in the EU are interrupted [9]. In this context, it is seen that a real financial integration process, in fact, aims at a complete integration of capital within the EU with an equal pure fit and integrity of monetary union. Real capital inflow and circulation can be defined as a common financial backdrop in which structural compliance questions are overcome.

Comprehensive information content, and in particular the creation of a strong analytical common financial framework, also confirms that political contradictions 
should be also overcome and resolved with a generally accepted common monetary policy. In this context, the main issue has been cope with these internal financial-monetarily conflicts for long years in EU, which ensure the financial integration. In brief, the monetary policy-based deviations of the political dilemmas related to the financial integration process gain negatively meaning through the harmonization process of the analytical financial structures [26]. In this context, exchange rate policies related to the different levels of development of each country, as well as the global capital integrations directly affected, put forth two important obstacles to financial cooperation. The first of these cases is the lack of a co-equal decision process in the establishment of the common monetary union and the serious critical casted out positions of some member states. This process is a process in which some countries, as if it is albeit indirectly, are excluded and the capital flows of global financial integration are negatively affected. The second is that occur via the negative deviations created by the exchange rate policies and the position of the EU for global capital movements [19]. In other words, countries with low exchange rates and high interest rates have left to choice produce different monetary and economic policies with per capita GDP.

This situation has affected negatively the inter-country bank and treasury transactions within the EU and results in a deviation of financial integration targets for recent years. Therefore, rather than the common financial policies, differences in implementation of monetary and financial policies have played an active role at the basis of political possible contradictions. As long as the differences in implementation are not overcome by structural adjustment policies, it is seen that the target financial reforms in the EU are in a non-effective-weak process which mean a financial alteration-integration process that depend on the undesired structural dynamics. However, for the EU, money markets for financial integration on the basis of member countries also vary between organized institutional markets and non-organized markets. The less financially organized structure of the newly developed or developing new member states also directly affects the capital markets. Considering that the organized financial markets are particularly Banks and the Central Government Treasury Agency, less developed countries cannot achieve a desired capital flow through the exchange rate policies they apply.

The position of the political dilemmas and the developed-weighted countries in the financial decision-making process causes the funds provided for the global capital flow to be directed to the different financial need channels for different market formations [14]. This structure that can be defined remarkable political dilemma, which continues with the effect of different exchange rate policies, has represented a process in which the short-term funds needed by the markets are also adversely affected for approximately twenty years. However, the real impact of the needs for long-term funds aimed at a real economic development, especially for less developed member countries, needs more savings and funds. However, it appears that the present exchange rate politics that have been controlled via developed countries in EU cause to deviation the delivering of funds and savings sustainability limits. Newly developing countries that are far from this financial stabilization face significant real losses due to the effects of exchange rate differences within the scope of practices for secondary financial markets. This present situation should be evaluated as a structural-institutional position that is as related to political infrastructures, which cause the political-financial conflict with especially together with countries that have more powerful exchange rate politics in the aimed at developing process in EU [27].

\subsection{The Structural Alteration Dynamics Framework of the Financial Integration Solutions}

The sub-dynamics of financial integrations in the EU and the institutional elements subject to the adaptation process are also seen as the dynamics of the integration process. In addition to, the banking, treasury and mortgage applications that constitute the essence of the financial structure for all the member countries, the funds related to insurance transactions also reveal significant corporate dynamics. In this context, the structure of the financial integration process, which supports global entrepreneurship and joint performance management, is being tried to be overcome with financial transactions level and financial consolidations. It should be emphasized that the integration process expresses the process of integration in relation to capital movements [28]. At this point, it is understood that the position of capital movements, which increases the savings and makes the investments attractive, has an important place in the process for financial integration. This involved relationship related to the alteration and solution process in EU can be seen on the Table1, below: 
Table 1. The Alteration Dynamics Framework of the Financial Integration

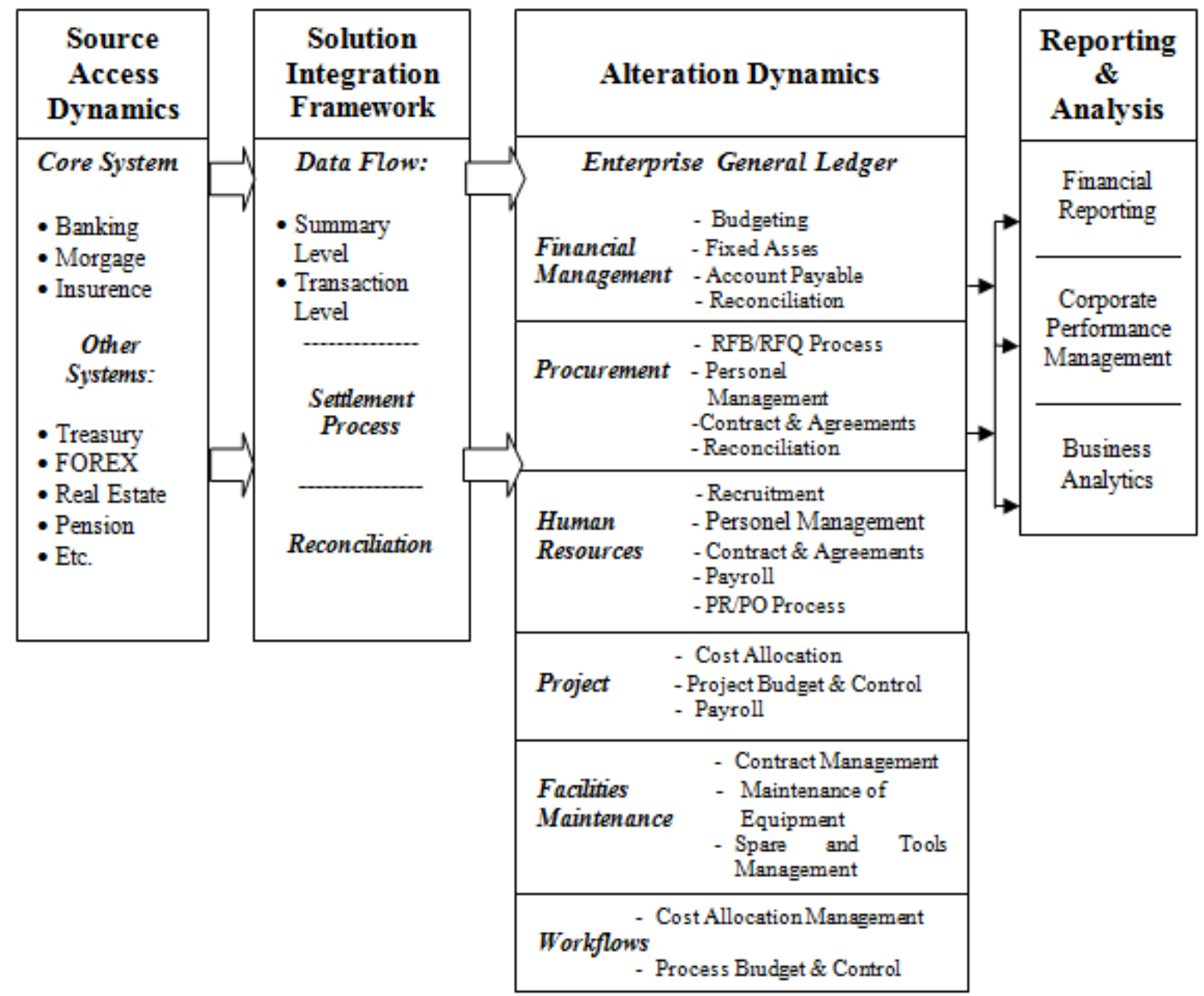

Source: A-finteg, https://www.a-solutions.dk/industries/a-solutions-domains/a-finteg/

As can be seen in Table 1, it can be said that the dynamics of the financial integration process in the EU have gained meaning in three main categories. The most fundamental phase is the alignment of banking and institutional-rational systems based on the institutional systemic structure. The financial position of the buildings that exhibit financial value such as real estate financial transactions and their monetary lending values put forth an important financial change, even if it is indirect, to alteration dynamics framework. In this structural location the point to be overcome in terms of financial integration is to ensure a healthy and rational information flow in the harmonization of financial transactions and to introduce the balance of financial transactions in terms of member countries.

At this stage, an institutionalized financial integration process has to be understood with a significant compromise ground and its institutional internal dynamics. In this respect, the need to overcome and solve the financial integration problems necessitates the balancing of the financial transaction levels in this area. In addition to, the common institutionalization process must also provide institutional solutions to the stable processes of this resident structure. This fact results in that differentiates the financial transaction levels in the integration process is that it is due to the different levels of financial transaction costs associated with the countries [17]. This process, in which the difference in development between countries is also effective, has a direct impact on the contribution of the financial budget accounts and joint financial projects to the joint budget contributions. In this respect, each change in the financial integration dynamics has to balance the costs arising from capital mobility and the agreement costs in the management of the process.

This phenomenon related to the corporate process has also revealed some significant deviations in terms of financial integration for a long time directed to EU countries. From this different point of view, this structural differences regarding institutional agreements and paid fees have a negative effect on the use of human resources in the integration process [30]. Exceeding this negative process makes a common business analytics and performance management shaped on the basis of financial reporting inevitable. Each different location of the 
management tools reveals a position where integration costs are further increased. At this point, the EU members have put forward the integration process with a common benefit-altruism approach to joint financial projects, where over a long period of time has been a priority for creating mutual defense values. Addition to, these member countries have keep on their structural allegations more and more in the recently years. It appears that the most important remarkable financial integration's issues have occurred at this access point, which effect on the relationships in each country for the same process in EU. On the other hand, the contradictory structure of the common monetary policy implementations in the EU causes significant liquidity crises and adversely affects the financial integration process [7].

It is not possible to consider these dynamics from each other's being separately, which is related to the financial integration process. This process, in which the financial information flow is asymmetric, reveals a process in which financial reporting is also transformed into a different business analytics and disrupts the distribution balance of financial integration process costs in the across countries. When considered as an expression of monetary, commercial and common capital movements, financial integration for the EU reveals the inevitability of a common European Union budget of all these change dynamics. This common budget refers to the contribution to the common budget, rather than the change in the national budget of each member state [6]. These contributions are also a requirement of the common financial control conditions along with the contributions to the costs of corporate financial integrations. In this respect, the financial integration process for the EU can be perceived as a definition of a process that presents its own solutions in the same process with the structural integration policies [12].

\section{The Accomplice Policies towards to Overcoming Possible Problems in the Process of Financial Integration}

The problems related to the financial integration process are possible politic structural factors that can be considered within the common-integrated framework for AB. In another way, the financial development level of the EU countries in the process of financial integration is directly related to the distribution of the risks of financial integration process between the member states. In this respect, the financial integration process within the EU is shaped by the risk variation related to the process and the results of the consumption-investment relationships. The existence of possible adaptation problems in the process capital flow regression values and institutional development level is in as a value inversely proportional to the integration level [5] (Cipriani, 2016: 7). This put forth phenomenon undoubtedly reveals the dynamics of the future political elements and structural measures to overcome the problems arising from the integration process

\subsection{The Evaluation Dynamics Related to Overcoming Issues of the Financial Integration Process}

The risk allocation and sectoral support position of financial integration among the member countries needs a significant infrastructure requirement. In this framework which can be addressed, certainly these structural approaches also reveal the contents of policies and reforms. Each change in which the legal and feasibility ground is targeted sets out the dynamics of the reforms related to the process and at the same time initiates a process of institutional new formations. In this concerned process of financial integration for the EU, the change-development process of the dynamics of integration aims to certainly accelerate the capital formation process on the basis of the member countries and to reveal more clearly a common objective with the dynamics that constitute the economic growth targets of the development of capital markets. This structural is the most meaningful fact that aim to realize and put forth effective dynamics related to overcoming issues for consideration. This phenomenon also aims at the development of institutional infrastructure targets in overcoming the problems in the process. In this respect, the financial integration process requires a common set of problems. In this respect, the financial risks of the financial institutions that are traded within the EU and the policies and reforms introduced in overcoming these risks are important dynamics in overcoming financial compliance problems. Certainly, these dynamics also represent the objectives framework and limits of the intended joint financial integration. On the other hand, a systemic financial change process in the EU has also targeted and especially it should be noted that the financial changes in the implementation of the adaptation process also reveal a risk sharing process in the same period. Hence, the reform approaches in institutional arrangements also necessitated the consideration of the negative dynamics of development differences and financial structural differences among member countries. The dynamics of new financial approaches based on financial implementations to overcome potential problems related to the financial integration process can be seen in figure 2 below: 


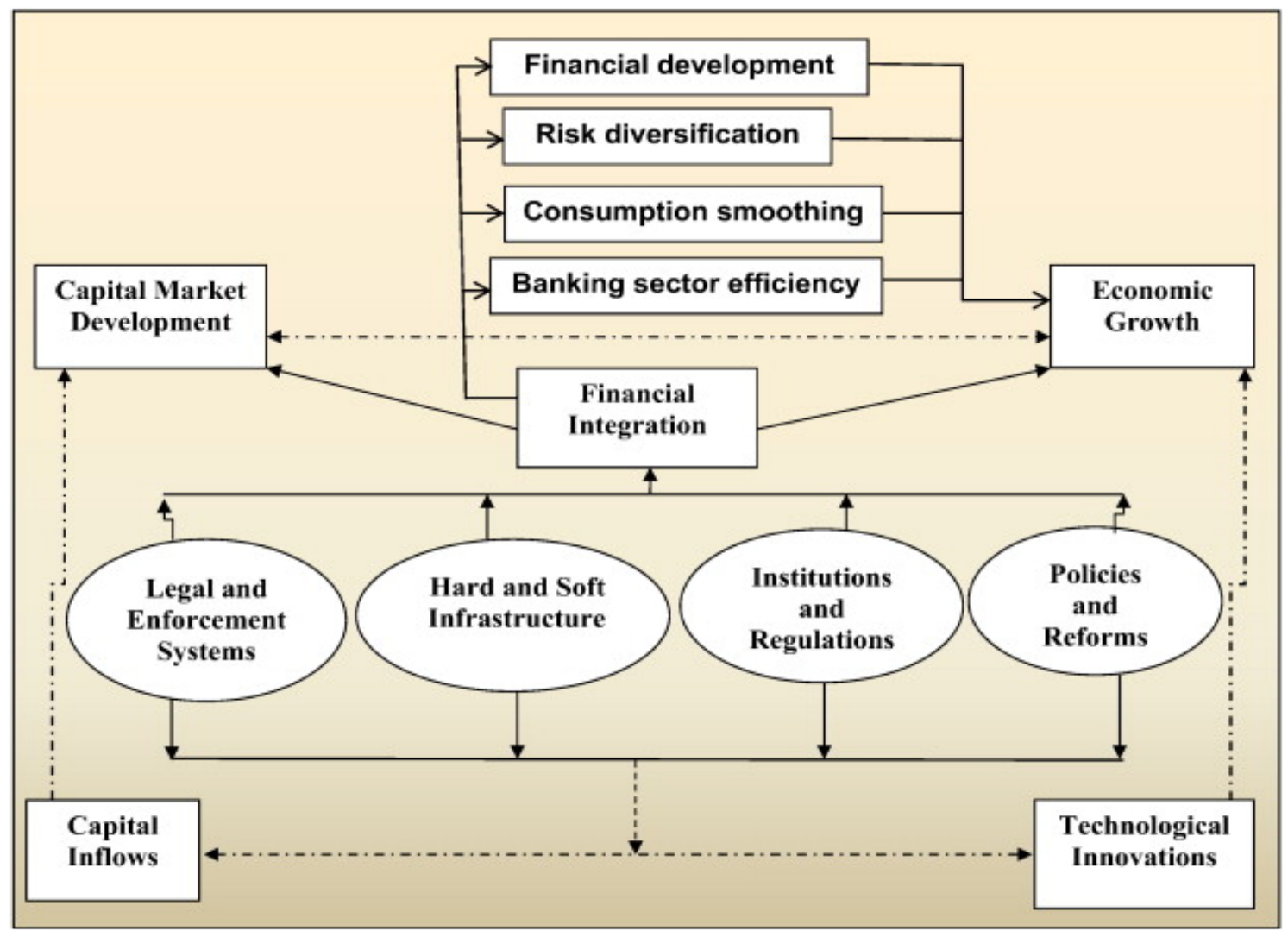

Source: Abdullahi D. Ahmed,and Kelesego K. Mmolainyane, "Financial Integration, Capital Market Development and Economic Performance: Empirical Evidence from Botswana”, Economic Modelling, 42, pp. 3.

Figure 2. The Financial Political-Institutional Infrastructure in deal with The Financial Integration Improvements Process

In the framework of the EU, it appears that a financial integration requires two types of institutional infrastructure. The first is the creation of a soft political transition-agreements ground in facilitating the adaptation process of less developed countries [13]. The second is the hard-convergent policies aiming at ensuring the equivalence of common monetary policies in practice [10]. Taking this approach into consideration, it is possible to say that the financial integration process is aimed at achieving four important criteria of change-compliance. Before all else, the first stage is to ensure the provision of a legal financial environment and a systematic common structure of financial practices [10].

These structural applications are primarily important because they emphasize the harmony and transparency of banking systems. It can be said that this is the main reason why the mandatory legal sanctions in the determination of policies aimed at joint money use practices are highlighted. The second is the provision of joint infrastructural supports among the member states in the presence of the financial harmonization process. In the early stages of the implementation of common monetary policy, the structure is formed according to the soft and national preferences. The aim here is to ensure that the balance of payments system works well and effectively.

This includes coverage of foreign exchange reserves. At this stage, the objectives of ensuring harmonization between national central banks and a EU-federated central bank are predominantly leading to the financial front choices. This process would put forth whether using Euro system in the financial integration process especially to less developed member countries throughout this alteration-transforming period. The third structural dynamic related to the overcoming of financial integration issues is what the location of institutional cohesion, and institutional arrangements for the financial integration process are [15]. At this stage, it is aimed to remove the mutual constraints of different bank applications between the member countries and to highlight the importance of global cooperation.

The classification of bank capitals against shocks is also among the priority issues that are addressed at this stage for structural adjustment, and the aimed policies should be regulate and put forth in connected with the process. This adaptation process of the structural alteration formatting is an important substructure stage in terms of modernization and financial efficiency while reducing the negative competition among banks. Because this process provides an important basis for overcoming the possible financial compliance problems in which a triple compliance of "Financial Markets", "Money Market" and "Capital Market", which is one of the main targets of financial 
integrations, is clearly addressed. Intergovernmental financial intermediaries, credit institutions, other monetary and financial institutions also aim at financial transparency to be established through a common banking approach especially construct these financial policies.

\subsection{The Aimed Structural Dynamics of the Financial Integration Process towards Financial Issues in EU}

It can be said that the fourth phase of financial integration for the EU has based on a goal-and-effect relationship in the first-three stages that we consider it related to the process. The reforms related to the process and the policies supporting these reforms are determined at this final stage and are already in the first step implementation phase. The policies in this final phase are not only about the integration process, but also as a mandatory economic growth policy to adapt to the objectives of economic policies. In particular, structural fiscal policies should be the main target of reforming the financial alterations in the framework of the Maastricht Treaty. However, it is difficult to say that the recent structural financial changes are in the framework of these international criteria. Especially, it is seen that there are important determinations that cause negative effects and harm this process in financial service provisions and financial assistances. At this point, it is seen that the most important problem is that financial intermediaries do not act in a common order and that common policy integrity cannot be reached in the approaches of EU common budget. To be directed towards the weak structure of the reforms, and the policies supporting within also support of free market criteria, it can be emphasized some approaches that are necessitates considering aimed at the integration policies and target financial reforms with their features below:

- $\quad$ The aimed more active and efficient work of financial institutions in the financial integration process necessitated reforms which necessitated the adjustment of credit margins related to financial credits distributions [18]. These reforms also form the framework for the structural changes of financial markets between countries. The reform arrangements have taken place in the process as a common goal of market harmonization and have made inevitable changes in the EU legislation in particular in the financial relations of the EU with third world countries.

- If this financial alteration fact is evaluated together with structural alteration dynamics for last recently years, it appears that the financial integration, monetary integration, globalization means a process that brings about market-based changes within the scope of possible innovation process. The process followed in recent years indicates that financial movements within the EU have shifted to a market-based financial base. In this stage the financing requirements of small and medium-sized companies have initiated the change process of EU-based financial support policies directed towards the future alterations [31]. It can be said that these reform-based changes have begun to shape the financial infrastructure of the new member states, whose financial structure is not strong enough. However, the insufficient change at this point represents a position that is far from the Euro Area in the framework of its financial advantages and manipulates the change requirements in this direction. Apparently, it is a possible requirement that all the financial structural reforms will be formed in the same categorical location in EU directed towards overcoming financial matters.

- $\quad$ The problem of financial integration within the scope of the EU can be said to be also emerged especially with the exchange rate policy pursued by the member countries. The case that needs to be overcome among the member countries have put forth a meaningful barrage that some undesired applications are included in the process apart from the standard European Central Bank applications. In the decisions of the Council of Europe on 13 December 1997 in Luxemburg about how the practices in the Eurozone should be made, it was emphasized that the value of the Euro should be a result of the practices rather than a policy objective. However, although the determination of the foreign currency denominated foreign currency requires the determination of the foreign currency values of the countries concerned, the significant deviations in the application result in significant monetary losses [8]. In this point, it is seen that the European Central Bank does not always carry out its monetary transactions with foreign currency transactions, and countries with high foreign exchange reserves cannot make significant positive contributions to the financial integration process as a conclude of significant financial losses.

- $\quad$ The important point that should not be overlooked here is that the scopes of the EU and Eurozone concepts have different qualities. This situation has two different meanings to overcome the financial problems in the EU. The first is that the institutional nature of the monetary policy has different fact despite the European monetary market is not an organ of European Central Bank. But, the competent authorities of European Central Bank are to requirement to work together with monetary market conditions under the same structural issues. In other words, the Central Bank of Europa determines the liquidity control in European Money Markets and the interest rate options based on these transactions, as well as marginal lending facilities and minimum required reserves, especially in particular the Open Market Operations in the Eurozone [8]. Moreover, the 
problems that arise for the $\mathrm{EU}$ in all foreign exchange-based transactions are one of the problems to be overcome today for financial integration. Alignment of the transactions for the money markets we mentioned in this way is severely disrupted by the fact that each member country does not accept the absolute common currency usage. The idea that the possibility of transformation into financial crises is due to this common use is a widely accepted view that financial integration policies constitute the most important obstacles in overcoming possible financial problems [25].

\section{Conclusions}

The financial integration process in the EU presents significant problems in terms of both structural dynamics and possible integration problems related to the integration process. This process, which expresses a process of conflict between the policies that put forth protectionist policies and a broader base of financial coherence, has also made it necessary to question the existing integration process against possible financial shocks. In other words, the level of advanced development and the different monetary price balances of each member of the European Union are considered as a significant obstacle to institutional integration. Moreover, this negative phenomenon also differentiates the national sensitivities of the financial crisis and draws the money market transactions out of the integration process.

It is seen that addressing these problems in two main categories has an important place in understanding the problems and providing possible solutions. First of all, it is necessary to define clearly that the system aiming at integration is based on a triple substructure arising from the credit market and financial management, and management sharing of authority on banking. While the definition of this net financial infrastructure provides a clear structural basis for overcoming the compliance problem of the member countries, it also provides a common set of criteria for the definition of common policies. But, this infrastructure that is far away from the aimed financial institutional assessments and it has appeared in the front of us as an important issue in the present days. Certainly, alignment of business analytics and capital market transactions in order to overcome the financial crises also have required a high degree of current adherence to these criteria and also provides the key to corporate changes. The other second structural element is that reform policies in the solution-oriented structural change policies are not at the desired level.

First of all, the banking system which constitutes the basic institutional structure of the integration process differs significantly within the EU and it is observed that negative differences are transformed into bigger problems during the implementation phase. This situation is one of the most important obstacles in front of institutional integrations, in which transnational debt transactions cause significant losses due to exchange rate differences or the depreciation of national currency against the Euro. From this point of view, financial integration has become a necessity that expresses a much more meaningful and common use and more sharing of capital than a common currency. However, it appears that this necessity has also suffered some significant weaknesses in policies such as the common crisis management and necessitated some countries to value their national currency at higher rates. A corporate integration that is considered a priority step beyond the use of a common currency is not seen as a highly successful process for the EU. The financial integration process has not yielded an absolute positive result, even in the case of a common tax reform, in addition to the national financial infrastructure changes in spite of that these nations resigned some preceding applications. In addition, the fact that less developed countries cannot find the support they want in the formation of a common tax concept is considered to be an important negativity. It is observed that the undeniable weight of the European Parliament in addressing the EU's common financial decisions has led to significant problems in the common implementation of the integration process, rather than solving the problems of the new integrated member states. In this respect, the financial integration process in the $\mathrm{EU}$ is required to balance the risk distribution process between the target capital market development and the countries' economic growth targets. This balance clarifies the common dynamics of the common monetary and fiscal policies on the EU level, but also necessitates a balanced capital flow as an important requirement for ensuring financial integration.

\section{REFERENCES}

[1] Abbassi, P., Bräuning, F., Fecht, F. and Peydro, J. L. (2017), International Financial Integration, Crises, and Monetary Policy: Evidence from the Euro Area Interbank Crises, FRB of Boston Working Paper No. 17-6, September 2017.

[2] Ahmed, A. D. and Mmolainyane, K. K. (2014), "Financial Integration, Capital Market Development and Economic Performance: Empirical evidence from Botswana”, Economic Modelling, 42, pp.1-14.

[3] A-finteg, https://www.a-solutions.dk/industries/a-solutions-domains/ a-finteg/ (26.03.2109).

[4] Alcidi, C. (2019), "Economic Integration and Income Convergence in the EU, Intereconomics", Intereconomics-Review of European Economic Policy, Vol. 54, No: 1, January/February 2019, pp. 5-11.

[5] Cipriani, G. (2016), Reforming the EU's Budget Revenue 
The Case for a Visible VAT-Based Resource, CEPS Special Report No. 150 / November 2016.

[6] Downes, R. Moretti, D. and Nicol, S. (2017), Budgeting and Performance in the European Union A Review in the Context of EU Budget Focused on Results, OECD Journal on Budgeting Volume 2017/1, OECD 2017.

[7] Emter, L., Schmitz, M. and Tirpák, M. (2018), Cross-Border Banking In The EU Since The Crisis: What Is Driving The Great Retrenchment?, Working Paper Series, No 2130, Frankfurt am Main: European Central Bank, February 2018.

[8] Grüner, H. P. (2013), The Political Economy of Structural Reform and Fiscal Consolidation Revisited, European Commission-European Economy Economic Papers 487, April 2013, Brussels: European Commission Directorate-General for Economic and Financial Affairs, 2013.

[9] European Central Bank (2016)a, Financial Integration in Europe, Frankfurt am Main: European Central Bank, April 2016.

[10] European Central Bank (2016)b, Convergence Report-2016, Frankfurt am Main: European Central Bank, June 2016.

[11] European Central Bank (2018), Financial Integration in Europe, Frankfurt am Main: European Central Bank, May 2018.

[12] European Commission (2017), EU Budget 2017 Financial Report, Luxembourg: Publications Office of the European Union, 2018.

[13] European Environment Agency (2014), National Adaptation Policy Processes in European Countries 2014, EEA Report No 4/2014, Luxembourg: Publications Office of the European Union, 2014.

[14] European Parliament (2012), The Role Of Brics in The Developing World, EXPO/B/DEVE/FWC/2009/01/Lot5/24, Brussels: Directorate-General For External Policies of The Union Directorate Policy Department Study, April 2012.

[15] European Parliament (2018), Overcoming innovation gaps in the EU-13 Member States, Study IP/G/STOA/FWC/2013-001/LOT 8/C4, Brussels: European Parliamentery Research Service (EPRS), Scientific Foresight Unit (STOA), PE 614.537, March 2018.

[16] Haiss, P. and Sammer, B. (2010), The Impact of Derivatives Markets on Financial Integration, Risk, and Economic Growth, Paper presented at the Bundesbank / Athenian Policy Forum 10th Biennial Conference on "Regulatory Responses to the Financial Crisis”, Frankfurt, DE, 28-31 July, 2010.

[17] [Hemmelgarn, T., Nicodème, G. Tasnadi, B. and Vermote, P. (2015), Financial Transaction Taxes in the European Union, Taxation Papers Taxation and Customs Union Working Paper N. 62 - 2015, Luxembourg: European Commission, Office for Official Publications of the European Communities, January 2016.

[18] Kenny, G. and Morgan, J. (2011), Some Lessons from The Financial Crisis for The Economic Analysis, European Central Bank Occasional Paper Series No 130 / October
2011, Frankfurt am Main: European Central Bank, October 2011.

[19] Lane, P. R. (2013), Capital Flows in the Euro Area, European Economy Economic Papers 497 | April 2013, Brussels: European Commission Directorate-General for Economic and Financial Affairs, 2013.

[20] Macro Ops, https://macro-ops.com/chinas-mundell-flemin g-trilemma/ (18.03.2019).

[21] Masoud, N. M. H. (2013), “The Impact of Stock Market Performance upon Economic Growth”, International Journal of Economics and Financial Issues, Vol. 3, No. 4, pp.788-779.

[22] Moghadam, R. (2014), "Europe’s Road to Integration”, Finance \& Development, Vol. 51, No. 1, March 2014, pp. 8-13.

[23] Niemann, A. and Ioannou, D. (2015), "European Economic Integration in Times of Crisis: A Case of Neofunctionalism?” Journal of European Public Policy, Vol. 22, Issue 2, pp. 196-218.

[24] Pierdzioch, C. (2002), Financial Market Integration and Business Cycle Volatility in a Monetary Union, Kiel Working Paper No. 1115, Kiel: Kiel Institute of World Economics, July 2002.

[25] Rosiak, T. (2015), "Fiscal Capacity for Euro Area Towards a Bigger EU Budget?”, Oeconomia Copernicana, 6(3), pp. 45-60.

[26] Orbie, Jan (2016), Europe's Global Role: External Policies of the European Union, Routledge, 2016.

[27] Stigliz, J. (2016), The Problem with Europe is Euro, https:/ /www.theguardian.com/business/2016/aug/10/joseph-stigli tz-the-problem-with-europe-is-the-euro, (09.04.2019).

[28] Stirbu, C. (2004), Financial Market Integration in a Wider European Union, HWWA Discussion Paper 297, Hamburg: Hamburg Institute of International Economics (HWWA), October 2004.

[29] Suardi, M. (2001), EMU and Asymmetries in Monetary Policy Transmission, Economic Paper, ECFIN/435/01-EN, Number 157, July 2001, European Communities, 2001.

[30] Wilson, R. A. and Briscoe, G. (2004), The Impact of Human Capital on Economic Growth: A Review, Third report on vocational training research in Europe, Background Report - Cedefop Reference series, 54, Luxembourg: European Commission, Office for Official Publications of the European Communities, 2004.

[31] Zadeh, Y. G. (2012), Avrupa Birliği'nde Finansal Entegrasyon: Bankacılı Sektörü Açısından Bir Değerlendirme, Basılmamış Yüksek Lisans Tezi, Ankara: Ankara Üniversitesi Sosyal Bilimler Enstitüsü, Avrupa Birliği ve Uluslararası Ekonomik İlişkiler (Ekonomi Maliye) Anabilim Dalı, 2012. 